\title{
Africana
}

\section{World War I and the Rise of African Nationalism: Nigerian Veterans as Catalysts of Change}

by James K. Matthews, Historian, Department of the Air Force, Headquarters Strategic Air Command, Offutt Air Force Base, Nebraska ${ }^{1}$

The enlistment and conscription of combatants and non-combatants in Nigeria during World War I represented an unprecedented mobilisation of the country's labour force. In September I914, the Nigeria Regiment supplied shock troops for the Cameroons Expeditionary Force, and in December I 9 I 7 the Nigeria Overseas Contingent entered the campaign in Tanganyika. By September 1919, when Nigeria's military recruitment drive ended, I 7,000 combatants, 2,ooo enlisted carriers, and some 35,000 non-enlisted carriers had participated in the Southern Cameroons and German East Africa campaigns. In addition, the British recruited thousands of Nigerians for military service along Nigeria's northern and eastern borders, and for related duties inside the country. ${ }^{2}$

These tens-of-thousands of Nigerian veterans acted as catalysts of change on their return home. Their experiences had altered ideas, attitudes, and habits during the war, and made them not only receptive to additional changes in the post-war years - especially socio-economic, military, and political - but also inclined to compel others to follow suit. The returned soldiers and carriers were, however, more accelerators of changes already under way in pre-war Nigeria than a force for new directions. ${ }^{3}$

1 The author was greatly assisted during his stay in Nigeria by Obaro Ikime and Robert Smith of the History Department of the University of Ibadan, and wishes to dedicate his article to the memory of John Barrett, whose study of 'The Rank and File of the Colonial Army in Nigeria, 1914-18' was published in this Journal, Vol. 15, No. 1, March 1976, pp. 105-15.

2 For somewhat conflicting statistics on Nigerian and other British West African World War I combatants and non-combatants, see Public Records Office, Kew Gardens, Colonial Office, 'Reorganization of the WAFF and KAR', 5 May 1919 , CO 445/48/27ı I ; A. H. W. Haywood to Secretary of State for the Colonies, London, 'Manpower - Native Races of West Africa', 3.July

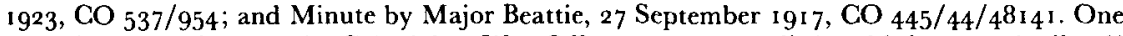
difficulty, unresolved by the Colonial or War Office, was' how to distinguish between 'enlisted' and 'recruited' carriers, between 'porters' and 'carriers', and between 'labourers' and 'carriers' . Sir Hugh Clifford to Colonial Office, is March ${ }_{192}$ I, CO $445 / 56 / 16908$.

For a discussion of the rôle played by West Africans during World War I, see James K. Matthews, 'Nigerian Military Experiences in the First World War: recruitment, service, and postwar change', Ph.D. dissertation, University of California, Santa Barbara, March I98I; also David Killingray and James K. Matthews, 'Beasts of Burden: British West African Carriers in the First World War', in Canadian Journal of African Studies (Ottawa), xiII, 1-2, Winter, 1979, pp. 6-23.

3 Similar conclusions have been reached by other scholars of Third-World nations. See Melvin Eugene Page, 'Malawians in the Great War and After, 1914-1925', Ph.D. dissertation, Michigan State University, 1977, and DeWitt C. Ellenwood, 'The Indian Soldier, the Indian Army, and Change, $1914^{-1} 9^{1} 8^{\prime}$, in Ellenwood and S. D. Pradhan (eds.), India and World War I (Columbia, 1978). 


\section{Socio-Economic Changes}

The war experiences of the veterans indubitably helped to accelerate linguistic change in Nigeria. At the minimum, soldiers and carriers had to learn commands in English. They adopted these and other words, which expanded and moulded their indigenous languages. For example, Hausa soldiers and carriers who went overseas "on ships... learnt the words "down below" for the vast holds in which bunks had been knocked up for them... and a "dambelo" became a large barge on the Benue', and eventually 'a cheap prostitute who takes any number of men each night'. ${ }^{1}$ Many soldiers also received advanced instruction in English. In September 1917 , in a report on training centres, Major G. W. Moran noted that 'a large number of men are rapidly acquiring English, and company commanders appear to take great pains in instructing and encouraging progress in this direction'.$^{2}$ Some, in time, even conquered the mysteries of reading and writing. ${ }^{3}$

Knowledge of the English language obviously benefited those seeking employment with the Government or European businesses, and the experiences of World War I had other important economic ramifications. Military service introduced thousands of veterans, their families, and other Nigerians to the money economy. After returning to their villages, some squandered their accumulated pay on gambling, gifts for women, and drink, while others invested wisely in land, homes, businesses, and wives. ${ }^{4}$ Regardless of how they spent their money, the veterans popularised its use. ${ }^{5}$ The appearance of coins and notes in the hinterland, where there had been little or none prior to 1918 , signalled the arrival of a new element in economic life. For Nigerians, it created a fresh form of wealth, one that offered the possibility of greater control over their own labour.

War service whetted appetites for a new range of foodstuffs and consumer goods. Tea, coffee, milk, sugar, flour, soda water, whisky, brandy, kerosene, soap, drugs, toilet preparations, and especially bicycles and European clothing were all very popular. ${ }^{6}$ Most of these could be found only in urban areas such as Lagos, Ibadan, Kano, and Calabar, where veterans were most likely to find wage-earning jobs comparable to those to which they had become accustomed. For many Nigerians, the allure of the city was too much to resist, and war service facilitated such geographical mobility. Thousands of Nigerians had not only been exposed to foreign travel for the first time, but they had encountered Europeans, Asians, and other Africans who had travelled from their homes as well. Men realised that there was a world beyond their villages and outside

1 Stanhope White, Dan Bana (London, I 966), p. 186.

2 G. W. Moran, 'Report on Training Centres', 3 September 1917, Nigeria National Archives, Ibadan, $20 / 5 \mathrm{NC}_{15} 8 / 17$.

${ }^{3}$ Samson Ukpabi, 'Military Recruitment and Social Mobility in Nineteenth Century British West Africa', in Journal of African Siudies (Washington, D.C.), II, I, 1975, pp. 87107.

4 Interviews conducted in July 1979 with No. 234 I I, ex-Sgt. Major Gbadamoshi Adedeji, I wo; No. 15307 , ex-Private Oyeleke, Ibadan; No. 1325 , ex-Corporal Afalabi, Ibadan; No. 4463 , ex-Private Baba Tunde, Ibadan; and No. 32584 , ex-Private Adeyemi, Ibadan.

3 Ukpabi, loc.cit.

- Interviews, Adedeji, Oyelek, Afalabi, Baba Tunde, and Adeyemi. 
their lineage groups. Consequently, migration to the city became an alternative to a comparatively uneventful life as a farmer. ${ }^{1}$

Wartime travel brought soldiers and carriers into contact with foreign ways of life, resulting in cultural exchange. F. W. H. Migeod later noted the arrival of the 'metallophone' in Sierra Leone:

I found a biscuit tin was used as a sound box and the half dozen steel notes were made from... knife blades ground down thin. This instrument does not belong to this country... The idea was brought back by natives who had been to East Africa in the war. ${ }^{2}$

There is evidence also of Hausa 'experiments in architecture of grass and bamboo construction' while the troops were in East Africa, as well as enthusiasm for gathering souvenirs such as cowries and other East African shells ' with the intention of presenting necklaces and waist belts to their womenfolk' 3 There were, undoubtedly, elements of cultural diffusion from West to East Africa, but their effect on African society needs to be studied more carefully. It would be equally interesting to determine what became of the West African carriers who, following the war, acquired relatively well-paid jobs as lorry drivers in Kenya. ${ }^{4}$

Contact with European science and technology was another factor that contributed to change in Nigeria. Before the war, the men knew only the casual, nature-oriented time-sense of the village; army life taught them a new concept of punctuality, compatible with reveille, parades, drills, and deadlines. Many Nigerians took their first ride on a train and saw their first car, aeroplane, and motion picture. Large numbers learned to shoot and care for modern weapons - not only rifles, but machine-guns and artillery. Also, soldiers and carriers learned basic hygiene, water sterilisation, and other methods of disease control and health care. Thousands of Nigerians received their first vaccination and took their first pill during the war.

Some African soldiers became especially familiar with European technology, The Nigerian Railway Department gave one month's intensive training in driving and mechanical maintenance to 280 Yoruba in preparation for their service with the West African Motor Transport Division. ${ }^{5}$ In December ig 6 ,

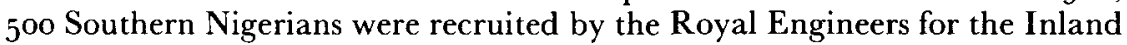
Water Transport Section and sent to Mesopotamia in early 19 I 7 as boatmen, mechanics, and dock hands. ${ }^{6}$ Other Nigerians received special traning as operators and linesmen for the Signal Section; as sappers, miners, and engineers for the Pioneer Company; and as medical assistants for base and field hospitals. The high incidence of casualties during the war meant that large

1 Page, op.cit. and Ellenwood, loc.cit. have made similar observations.

${ }^{2}$ F. W. H. Migeod, A View of Sierra Leone (London, 1926), p. 186.

3 'A Reader of West Africa in East Africa', in West Africa (London), i I January igig.

4 Ibid.

${ }^{5}$ Railway Department to Central Secretary, 16 January 1918, CSO $19 / 6 \mathrm{~N}_{446 / 1}$; Central Secretary to AG Base, Dar es Salaam, 25 March 19 I 8, CSO I9/6 N 607/ 8 ; Treasury Department (Hyatt?) to Central Secretary, 31 December 19 r9, CSO $19 / 8 \mathrm{~N} \mathrm{49/20}$. This unit, which included men from the Gold Coast, sailed to Dar es Salaam in late 1917 and returned to Lagos and Accra in mid-1919.

${ }^{8}$ Lugard to A. B. Law, i December $1916, \mathrm{CO}_{5}^{8} 3 / 5^{\circ} / 8_{44}$. 
numbers of men spent time in hospitals, where they witnessed advanced medical techniques, including amputations, prosthetics, and plastic surgery.

Most Nigerians accepted the new technology in a professional, workmanlike way, and those on leave in Durban, for example, seemed to display no cultural shock. According to one of their officers:

the men, who could never in their lives have conceived the existence of such a town as Durban with its harbours, shops, electric tram, cinema theatres... were to all appearances less impressed by what they saw than were the inhabitants of Durban themselves at the unusual sight of such a body of fully trained African troops. ${ }^{1}$

Although the men may not have been as enthusiastic about European technology as their officers expected, most were definitely impressed. When asked what the English had taught him during the war, ex-Private Oyeleke replied: 'They taught me to shoot by lying down and standing. How to use rifles and machine-guns, and how to take them apart and put them together again... I liked it very much'. Following the war, he bought some mechanic's tools with his savings and made money 'fixing things'.2

Testimonials by veterans showed that Nigerians also reacted favourably to European medical practices. Baba Tunde, who spent four months in a hospital in Dar es Salaam with a foot wound, was forever grateful to English doctors for allowing him to 'walk like a man again'. 3 The go-year-old Oyeleke was equally convinced of the benefits of European medicine: army doctors taught him 'how to live long'. 'In fact, access to European medicine was one reason why the soldiers were healthier as a group than the population as a whole. In a letter to the Acting Governor-General explaining why relatively few military men had died from influenza during the devastating epidemic of I9 8 , Dr J. Beringer, Medical Officer of Health at Lagos, reported: 'Soldiers are compelled or accustomed to have skilled medical treatment with consequent lessening of the death rate'. 5 It seems a valid conclusion, then, that the military experience of Nigerians made them, and perhaps their families and friends, more likely to accept modern technology in general, and western medicine in particular.

\section{The Military Institution}

A tight post-war budget hindered the army's modernisation programme, initiated in 1914 with the creation of the Nigeria Regiment. ${ }^{6}$ Previously, for instance, the colonial authorities had wished to increase the number of British N.C.O.s in the Regiment to improve army training. Following the war, however, funds were unavailable for additional British sergeants or even replacements for those whose term of service had expired. The way in which the British solved this problem resulted in a 'Nigerianisation' of the Regiment's

1 E. St. C. Stobart, 'A Record of the Doings of the Nigeria Regiment during the Campaign in German East Africa, December 1916 - December 1917', i2 April 1919, CO 445/47/28875.

2 Interview, Oyeleke.

3 Interview, Baba Tunde.

4 Interview, Oyeleke.

$5 \mathrm{~J}$. Beringer, Medical Ufficer of Health, Lagos, to Andrew Boyle, Acting Governor-General, 30 October $1918, \mathrm{CO} 583 / 74 / 28850$.

${ }^{6}$ Colonel A. H. W. Haywood and Brigadier F. A. S. Clarke, The History of the Royal West African Frontier Force (Aldershot, I 964 ), p. 319. 
non-commissioned officers. Prior to demobilisation, more Nigerian sergeants and corporals than were authorised in the Regiment's peace-time establishment made it known that they wished to remain in the service. According to the Acting Governor-General, it was

hardly conceivable that these NCOs who have gained their rank by virtue of good work in the field should be forced to choose between serving as Privates or a lower rank than which they previously held. I submit that the only fair way to deal with these cases would be to allow the NCOs to retain their rank and make them 'supernumerary' until the time they can be absorbed. 2

The Colonial Office agreed, adding that the increase in Nigerian N.C.O.s would be paid for by a corresponding decrease in British staff.

To ensure uniform instruction, the British opened a school at Zungeru in early I $_{1} 8$ to train many of these young Nigerian N.C.O.s as teachers. British personnel and senior Nigerian N.C.O.s staffed the school, and introduced a syllabus of instruction for a six-week course based on their experiences in the Cameroons and East Africa campaigns. By the end of the year, nearly 200 Nigerians had qualified as instructors in drill, musketry, bayonet, machine-gun, signalling, and lower-standard English. ${ }^{3}$ Thus, during the post-war era Nigerians began to fill many posts previously held by British N.C.O.s, a process that gave increasing numbers of them positions of leadership in the army and helped to reduce the Regiment's payroll expenditures.

There was another important post-war change in the army's training programme. The superb work done by Africans during the war reinforced the Colonial Office's belief that the West African Frontier Force and the King's African Rifles should make a greater contribution to the defence of the Empire. In fact, between the two world wars a variety of influential officials and public lobbies in London argued that African troops should be used as combatants and non-combatants in limited theatres, and that an African force should be created as a parallel to, or a replacement for, the Indian Army. ${ }^{4}$ Consequently, when funds permitted, Nigerian units were concentrated for war games in preparation for the Regiment's possible rôle as an imperial force outside of Africa. ${ }^{5}$

Post-war financial straits influenced miliary modernisation in other ways. Late in I 18 , General Frederick Cunliffe requested that his officers should draw upon their war experiences and submit recommendations for improving the effectiveness of the Nigerian military. ${ }^{6}$ Medical officers were unanimous in their desire to have Africans trained as stretcher-bearers, and medical assistants become part of the Regiment's permanent establishment. ${ }^{7}$ Because of the

1 Andrew Boyle to Secretary of State for the Colonies, 20 October 1918, CSO 19/6 N 2736/18.

2 Colonial Office to Lugard, 27 March 1919; ibid.

3 G. W. Moran, 'Report on Training Centres', 26 January 19 1 8, CO 445/44/ I8468; Cunliffe's

'Recommendations for Reorganization of the West African Frontier Force', in Boyle to Milner, March $1919, \mathrm{CO} 445 / 47 / 23456$.

'David Killingray, 'The Idea of a British Imperial Army', in The Journal of African History (Cambridge), 20, 3, 1979, pp. 42 1-6. See also his Ph.D. dissertation, 'The Colonial Army in the Gold Coast: official policy and local response, 1890-1947', University of London, 1982.

${ }^{5}$ Haywood and Clarke, op.cit. p. 323.

- E. C. Feneran to Cunliffe, 26 December 1918; T. Sargent to Cunliffe, 9 February 1919; and G. D. Mann to Cunliffe, 26 December 19 18; CO 445/47/23456.

7 T. M. Russell Leonard to Cunliffe, n.d., ibid. 
excellent work done by the Gold Coast Pioneers in the Cameroons and by the Nigeria Pioneer Section in East Africa, military officers believed that an engineering unit composed of Nigerians should form part of an expanded colonial army. They also emphasised that any modern military force needed Lewis and Stokes gun-sections. ${ }^{1}$ All these suggestions were sound but impossible to implement because of lack of finance. Instead, the mounted infantry and one of the gun batteries were disbanded in 1922 for reasons of economy. ${ }^{2}$

The budget did, however, allow improvements in the Regiment's weaponry, clothing, and rations. Leather packs, for instance, were replaced by web haversacks, which were less likely to crack, resisted weather, and needed no saddlesoap, an item rarely available during the war. ${ }^{3}$ The rifles carried by machine-gunners in the Cameroons and Tanganyika tended to get caught on low branches, delaying assembly of their Maxims for action. Consequently, machine-gun crews were issued with revolvers instead of rifles. ${ }^{4}$ Also, the length of the bayonet often proved a handicap in the forest, so the British devised a special shortened 'bush' bayonet that became part of the infantry's standard equipment. The Nigerian's traditional weapon of close combat, the machete, proved its usefulness during the war, and it too became official weaponry. ${ }^{5}$

Problems created by inadequate foot-and-leg protection during the war led the British to conduct a field test of new footgear in I921. Medical officers in the First Battalion and the Battery issued their men with several different types of canvas and leather-topped boots. These were worn on duty and parade for I 8 days, after which the experiment was discontinued. Both the canvas and leather boots 'were found to be clumsy and made the wearers awkward and slow in movement. They complained that the large toe-cap hurt, and bruised the toe joints and the foot between the toes and the instep'. The guiding principle in the selection of footgear, the study concluded, must be that it provide protection when circumstances necessistated its use, yet not require regular wear for a comfortable fit. ${ }^{6}$ In 1923 , the Inspector-General announced that the official foot-and-leg gear of the W.A.F.F. was light-leather sandals with 'chupplies' over a grey worsted sock, although the men could still go barefoot on drill and patrol if they wished?

The hunger that the men experienced in the Cameroons and Tanganyika caused the British to make major improvements in their war rations. By World War II West African troops and carriers were on an official daily diet of 4,300 calories, which included pork, beef, beans, and chocolate, as well as rice and yams. Transport officers were even estimating the number of cigarettes, kola nuts, and sheets of toilet paper required for men in the field ${ }^{8}$

1 E. C. Feneran to Cunliffe, 26 December I9 18; T. Sargent to Cunliffe, 9 February ig I 9 ; and G. D. Mann to Cunliffe, 26 December $19^{18}$; $\mathrm{CO}_{445} / 47 / 23456$.

2 Haywood and Clarke, op.cit. p. 3 rg.

3 Lt. Colonel Gibb to Cunliffe, I March 1919, $\mathrm{CO}_{445 / 47 / 23456 .}$

4 Major Commanding $4^{\text {th }}$ Training Centre, Ibadan, to Jenkins, I3 April 1917, CSO $19 / 5 \mathrm{~N}_{1079} / 17$.

5 Cunliffe to Boyle, March 1919, CO 445/47/23456; and Haywood to Clifford, 25 May 1920, $\mathrm{CO} 445 / 5^{8 / 29804}$.

${ }^{6} \mathrm{~J}$. Sargent, Acting Commandant, to Governor-General, 18 July 1921 , $\mathrm{CO} 445 / 56 / 4228$.

7 'Report of the Inspector General for 1922', Kaduna (?), 28 May $1923, \mathrm{CO}_{45} / 62 / 26548$.

${ }^{8}$ F. A. S. Clarke, 'Recollections of an Area Commander in Africa', in Journal of the Royal United Service Institute (London), xcIv, I949, pp. 20-45; also Haywood and Clarke, op.cit. pp. 33 I-480. 


\section{Political Ramifications}

The nature of military life held the potential for radical political change. By mixing diverse peoples in the army, the British helped break down barriers between ethnic groups and replace them with bonds of friendship. This was especially true during the war, when it became impossible for the British to segregate ethnic groups by company. Men from Nigeria's north, east, and west not only spent time together on board ship, in hospitals, and on leave, but also found themselves fighting side by side in the same units. Yoruba Baba Tunde of B. Company, Third Battalion, for example, took orders from Hausa and Igbo N.C.O.s whom he called 'brothers', while Yoruba Sergeant Major Adedeji of C. Company, Fourth Battalion, issued orders to Hausa, who gave him 'no problems'.'

Specialised units, such as the Artillery, the Pioneers, the Signals, the Machine Gunners, and the Mounted Infantry, were even more heterogeneous. The latter had been almost exclusively Hausa before the war, but by 1916 were recruited from dozens of different ethnic groups. ${ }^{2}$ To facilitate communication within this unit and others, the British were forced to put increasing emphasis on English-language training, which also fostered Nigerian unity both in and out of the ranks.

Although the British were aware that increased contacts between different Nigerian ethnic groups were inconsistent with the colonial policy of 'divide and rule', they were much more concerned about the prospect of thousands of Nigerians - instilled with military discipline, organisation, and perhaps political ideology - returning to the Colony following the war. Disarming demobilised soldiers did not alleviate their fears. According to Colonel A. H. W. Haywood in I 920 , 'considerable quantities of arms and ammunition' had made their way into West Africa from the north. 'Owing to the circumstances of the war', he continued, 'a number of inhabitants of Nigeria have been trained to arms. We [the Regiment's Officer Corps] are thus led to the conclusion that in any future risings... the rebels are likely to be better armed and trained than they were in the past'. 3

Surprisingly, Nigerian veterans, who had been exposed to the cosmopolitan worlds of Lagos, Durban, Dar es Salaam, Bagdhad, and Bombay, who had established friendships that helped to break down the parochialism of ethnicity and provincialism, and who had been trained to arms and inculcated with army discipline and methods of organisation, did not attempt to overthrow their colonial masters. Apparently they did not even form political lobbies or self-help organisations. ${ }^{4}$ The fact that governments in general discouraged such

1 Interviews, Baba Tunde and Adedeji.

2 Nigeria and the Great War (Lagos, n.d.), CSO $19 / 5$ N i $735 / 17$. On p. 20 there is a photograph entitled 'The Tower of Babel - 12 men from one company, MI all of different tribes. Top row: Dekkakerri, Zeberma/Arriwa, Berri-Berri, Senegalese, Fulani. Bottom: Bauchi, Pagan, Barbarimis, Buzu, Hausa, Shewa Arba, Beddi'.

${ }^{3}$ Haywood to Clifford, 22 April i $920, \mathrm{CO} 445 / 5^{1 / 29803}$.

4 My research disclosed no documentation on the existence of a veterans association, and none of those I interviewed had ever joined or even heard of such a group. In addition, Chief Olyonu of Ibadan, who was instrumental in establishing the Nigeria Legion, which brought together a number of post-World War II ex-servicemen's organisations in 1964, and Colonel Akafar, the Secretary of the Nigeria Legion, Ibadan, told me that they had been unable to find any record of post-World War I veterans associations. 
activity among veterans helps to explain their basically apolitical nature, a common characteristic of ex-soldiers in both Europe and British Africa. ${ }^{1}$

The Nigeria Regiment's reputation among the civilian population also helps explain why veterans did not become political leaders. While Nigerians were winning kudos overseas, the garrison troops at home were perpetuating the Regiment's negative image. ${ }^{2}$ Their punitive behaviour, ostensibly justified because of the delicate internal situation precipitated by the war, convinced many Nigerians that the Regiment was an oppressor, the instrument of British imperial policy. This image acted as a counterbalance to the unity achieved by various ethnic groups within the Regiment while fighting overseas. Ironically, it was this camaraderie, forged on the battlefield, that might have helped transform the Regiment into a respected mechanism of national integration, the antithesis of indirect rule.

Although Nigerian veterans were not highly political, they did help to build a new political order. Their military discipline and foreign travel, plus their exposure to the English language, the money economy, modern technology, and other aspects of European culture, accelerated the country's move into the twentieth century. In addition, their war experiences increased their selfconfidence and sense of self-worth, character traits inextricably linked with the growth of a national consciousness.

A new unity based on race also emerged; Nigerians were proud of their contributions to victory and their ability to excel in battle as a modern military force. A letter to the editor of West Africa, criticising the tendency of Europeans to attribute African successes in the Cameroons and East Africa to white leadership, clearly expresses this new-found pride in race:

It is in no vaunting or glorifying spirit that $I$ remind the European that the race which smashed the British squares at the Soudan, and the race which, with bare hands and assegais, charged in a frontal attack the British machine guns and got to within 17 yards of those deadly weapons in South Africa, and the race whose fighting qualities compelled General Smuts to advise Europe to make a cardinal law of the League of Nations... the definite non-arming of the African, has defensive instinct which can successfully function without European leadership. ${ }^{3}$

Nigerian participation in the world conflict encouraged national identity in other ways. The mobilisation of Nigeria's manpower during World War I forced very many Africans, previously ignorant of any political unity outside their own village, to recognise the existence of a much larger territorial entity and to participate for the first time in Nigerian affairs. There was also a shared sense of suffering. Demobilised veterans returned home to relate their trials and tribulations to family and friends. Those who were maimed served as visual reminders of Nigerian sacrifice, and the families of men who did not return grieved together.

Nigerian veterans hastened, directly and indirectly, the decline of the old political order. They witnessed, at first hand, Europeans fighting among themselves. They no longer regarded whites as a monolithic race, but instead

1 See Steven R. Ward (ed.), The War Generation : veterans of the First World War (New York, 1975), for studies of British, American, French, Italian, and German veterans associations.

2 Samson Ukpabi, 'The Changing Role of the Military in Nigeria, 1900-1970', in Afrika Spectrum (Hamburg), 76/1, pp. 61-77.

3 Victor Allen of Lagos, West Africa, 17 January 1920. 
saw them as 'tribes' quite capable of being divided. Some Nigerians had killed Europeans in and out of battle. When asked what became of German officers captured in the field, Adedeji replied, 'We poured petrol or kerosene over them and set them on fire while alive'. ${ }^{1}$ Although this is probably an exaggeration on the part of an old man hoping to impress his interviewer, grandchildren, and neighbours, it illustrates how the war changed Nigerian perceptions of Europeans. Like other men, Europeans were vulnerable and in the long run could be defeated. In general, Nigerians were less likely to fear men simply because of their colour or nationality.

Ironically, World War I, fought by Britain to maintain and strengthen its power world-wide, helped erode its might and prestige in Nigeria. The educated élite, who had expected that their steadfast support of Britain would be rewarded by the recognition that Africans were adults entitled to be treated as such, had to wait until after World War II for any meaningful share in their government. They were not alone in feeling cheated. Thousands of Nigerians, after years of faithful service in the Regiment, received no back pay, gratuities, or medals; Nigerians, rich and poor, contributed generously to various relief funds without any apparent benefit to the veterans or their dependents. ${ }^{2}$ When asked what the British did for the families of dead soldiers, Baba Tunde answered: 'The Government did not care about the families... did not even take care of living soldiers... The British could not be trusted' ${ }^{3}$

World War I served in other ways to discredit the British in Nigeria. Colonial officials, military officers, and the British press heaped praise upon the men of the Nigeria Regiment; yet $3^{0}$ years passed before a Nigerian was promoted to the officer corps. The educated élite was quick to point out that Africans in the French territories served as officers, even generals: "These men have only risen by their brave endeavours, but we who are under the British flag cannot get above the rank of Sergeant Major, and what we were entitled to we did not get'.

Although the British refusal to grant commissions to West African veterans incensed the educated élite, one particular post-war injustice convinced many West Africans that they would not share in the fruits of victory. The Nigeria Regiment, sent to the East Africa theatre to replace white troops suffering severely from the effects of the tropical climate, was not given any opportunity to take part in the London Peace Parade; the Colonial Office concluded that it would be 'impolitic to bring [to England] coloured detachments to participate in the peace processions'. ${ }^{5}$ A letter by Victor Allen of Lagos to the editor of West Africa articulated the righteous indignation felt by those who were stung by this insult:

In your issue published the week after the Victory march in London, you asserted that Africans could not be in the march because there was no time to get them to England owing to lack of

1 Interview, Adedeji.

2 See James K. Matthews, 'Clock Towers for the Colonised: demobilisation of the Nigerian military and the readjustment of its veterans to civilian life, $1918-1925$ ', in International fournal of African Historical Studies (New York), I4, 2, 1981, pp. 254-71.

${ }^{3}$ Interview, Baba Tunde.

4 Victor Allen, West Africa, i October 1919.

${ }^{5}$ Colunial Office minute by Colonel Jenkins, 15 October, 1919 , CO $5_{3}^{8} / 7^{6 / 51430}$. 
transport. You do not mean to say that Great Britain could not afford to send out two men-of-war to bring them if they had been wanted?... They were fit to assist in breaking the aggression of Germany but they were not fit to be in the Victory march... We live and learn. ${ }^{1}$

Indeed, Nigerians would long remember this 'petty and penny-pinching piece of trivial racism'. ${ }^{2}$

British methods of recruitment during World War I also lowered their prestige in Nigeria. ${ }^{3}$ For instance, people in the North were heard saying in 1916: 'Here have these... Christians been for twenty years preaching and legislating against slavery, and they themselves are slave-raiding our villages and taking children to fight for them'.4 The impressment of soldiers and carriers not only exposed the hypocrisy of European religion, but also struck at the heart of indirect rule. Throughout Nigeria, the British pressured chiefs and headmen into meeting manpower quotas, a process that alienated the people from their traditional leaders. E. M. Falk, the District Officer at Owerri, in south-eastern Nigeria, reported in May 1919 that the 'relatives of men who have not come back from military expeditions or railway work invariably consider the chief who recruited the men to be guilty of a species of homicide or slave dealing ${ }^{\prime}{ }^{5}$ Consequently, the families of soldiers and carriers who failed to return from the war inevitably held the chiefs responsible, and in some cases claimed compensation from them.

In 1918 , chiefs and headmen had to confront the demobilised military men they had sent to war. These cocky and sometimes hostile veterans, many of whom had held positions of responsibility in the military, challenged the authority of their traditional leaders. On his return to Iwo following the East Africa campaign, Adedeji found his chief unable to command the respect of the town's young men. When asked what the chief did to regain his authority, Adedeji replied: 'Nothing. The people would not listen'. ${ }^{6}$ By discrediting traditional authority, the British undermined the foundation of their own rule. Unwittingly, they helped create a political vacuum, to be filled by the increasingly nationalistic élite.

\section{Conclusion}

World War I created a commonality of experience in Nigeria that included both the erosion of traditional power and values and the building of pride and self-worth. Nigerians shared not only the suffering brought on by the fighting, but also - for the first time - a knowledge of European weaknesses and an understanding of what it meant to be colonised. In addition, many acquired a new and fundamental awareness that they belonged to a larger political unit. This conflict, in which the military man played the protagonist, was Nigeria's first national experience.

1 Victor Allen, West Africa, il October 1919.

2 Akinjide Osuntokun, Nigeria in the First World War (Atlantic Highlands, 1979), p. 297.

${ }^{3}$ See James K. Matthews, 'Reluctant Allies: Nigerian responses to military recruitment, 1914-1918', in Melvin E. Page (ed.), Black Men in a White Men's War (forthcoming).

4 Palmer to Lugard, 2 March $1917, \mathrm{CO}_{5} 8_{3} / 6_{3} / 3057$.

5 Memorandum from E. M. Falk to Resident, Owerri, 20 May 19 rg, NNA, Owerri Provincial Papers.

6 Interview, Adedeji. For similar accounts in West Africa, see Roger Thomas, 'Military Recruitment in the Gold Coast during the First World War', in Cahiers d'études africaines (Paris', $\mathrm{xv}, 57,1975$, pp. $57^{-8} 3$. 